\title{
Dampak adanya pandemi bagi Lembaga Bimbingan Belajar (LBB)
}

\author{
L. R. Madhani, K. A. Sari, D. K. Rahmawati, Desy Santi Rozakiyah* \\ Universitas Negeri Malang, Jl. Semarang No. 5 Malang, Jawa Timur, Indonesia \\ *Penulis korespondensi, Surel: desy.rozakiyah.fis@um.ac.id
}

Paper received: 01-04-2021; revised: 15-04-2021; accepted: 30-04-2021

\begin{abstract}
Covid-19 spreads so fast and has various impacts in society, one of which is in the world of formal education. The existence of a pandemic has resulted in learning to be carried out over a long distance network. This also has an impact on non-formal education such as the Tutoring Institution. LBB is an example of a non-formal education institution that guides students in academic lessons by adjusting their needs. The author tries to find the impact of a pandemic on LBB, what is felt by LBB and parents and students. This study aims to see the impact of the Pandemic Tutoring Institution, both formal and informal. This type of research is qualitative research using cognitive learning theory. Technique informants using purposive sampling technique. Sources of data used are interviews, observations, and literature studies. The results of the study explained that it would be healthy if LBB was kept open by implementing the Covid-19 health protocol, dividing students into several groups, and still maximizing courageous learning. The result of the research is that LBB must remain open because face-to-face learning is still needed by students who still need direct guidance such as kindergarten, elementary, and junior high school students/equivalent.
\end{abstract}

Keywords: tutoring institution; non-formal education; cognitive learning theory

\begin{abstract}
Abstrak
Covid-19 menyebar begitu cepat dan menimbulkan berbagai dampak di masyarakat, salah satunya pada dunia pendidikan formal. Adanya pandemi mengakibatkan pembelajaran harus dilakukan melalui jaringan jarak jauh. Hal ini juga berdampak pada pendidikan non formal seperti Lembaga Bimbingan Belajar. LBB merupakan salah satu contoh lembaga pendidikan non formal yang membimbing peserta didik terkait pelajaran akademis dengan menyesuaikan kebutuhan. Penulis berusaha mencari dampak adanya pandemi bagi LBB, apa saja yang dirasakan oleh pihak LBB maupun orang tua dan peserta didik. Penelitian ini bertujuan untuk mengetahui dampak adanya pandemi bagi Lembaga Bimbingan Belajar baik formal maupun informal. Jenis penelitian yang digunakan yaitu penelitian kualitatif dengan menggunakan teori belajar kognitif. Teknik pengumpulan informan dengan menggunakan teknik purposive sampling. Sumber data yang digunakan yaitu wawancara, observasi, dan studi literatur. Hasil penelitian menjelaskan bahwa alangkah baiknya jika LBB tetap dibuka dengan menerapkan protokol kesehatan Covid-19, membagi peserta didik dalam beberapa kelompok, dan tetap memaksimalkan pembelajaran daring. Dengan begitu kesimpulan dari hasil penelitian adalah LBB harus tetap dibuka karena pembelajaran tatap muka masih dibutuhkan oleh peserta didik yang masih membutuhkan bimbingan secara langsung seperti siswa TK, SD maupun SMP/sederajat.
\end{abstract}

Kata kunci: lembaga bimbingan belajar; pendidikan non formal; teori belajar kognitif

\section{Pendahuluan}

Wabah virus corona telah menyebabkan banyak kerugian di semua kalangan masyarakat dunia, tak terkecuali Indonesia juga merasakan dampaknya. World Health Organization (WHO) menetapkan status pandemi global covid-19 setelah virus berbahaya ini menyebar ke sebagian besar wilayah dunia. Artinya, penyebaran covid-19 begitu cepat hingga hampir seluruh dunia terserang virus ini (Mona, 2020). Hal tersebut mendorong pemerintah 
Indonesia mengeluarkan kebijakan Work From Home yaitu melakukan segala aktivitas dari rumah seperti bekerja, belajar, dan beribadah.

Menurut Milman dalam Firman, F., \& Rahayu, S. (2020) adanya teknologi digital memudahkan mahasiswa dan dosen melakukan proses pembelajaran meskipun berada di ruang yang berbeda. Salah satu bentuk alternatif pembelajaran yang dapat dilakukan selama masa darurat Covid-19 yaitu pembelajaran secara online atau dalam jaringan. Semua tingkatan pendidikan menggunakan pembelajaran secara online baik SD, SMP, SMA, maupun perkuliahan. Akan tetapi proses pembelajaran online belum dilakukan secara maksimal dikarenakan banyak sekali kendala yang dihadapi pengajar maupun peserta didik mulai dari terbatasnya fasilitas, keterbatasan sinyal, borosnya penggunaan paket data dan banyak lagi. Tidak semua peserta didik memiliki handphone yang saat ini menjadi kebutuhan terpenting di dunia pendidikan selama pandemi. Ada juga peserta didik yang memiliki handphone tetapi alat tersebut digunakan orang tua untuk bekerja. Sinyal di berbagai daerah juga belum dapat dikatakan kuat. Banyak peserta didik yang bertempat tinggal di daerah susah sinyal sehingga menghambat proses pembelajaran. Kemudian, banyak yang mengeluhkan borosnya penggunaan kuota saat pembelajaran daring. Pembelajaran via zoom maupun google meet menyebabkan kuota cepat habis. Padahal ekonomi orang tua saat pandemi sedang terhambat.

Disini pendidikan non formal mulai hadir untuk membantu berjalannya proses pembelajaran. Dalam undang-undang nomor 20 tahun 2003 tentang Sisdiknas disebutkan bahwa lembaga pendidikan non formal adalah jalur pendidikan di luar pendidikan formal yang dilaksanakan secara terstruktur dan berjenjang. Pendidikan ini tidak akan berjalan secara maksimal jika pengajar tidak mampu memberikan kontribusi yang positif bagi masyarakat di masa sekarang maupun di masa yang akan datang. Sama halnya di kondisi sekarang ini pendidikan non formal seperti Lembaga Bimbingan Belajar (LBB) lagi gencar-gencarnya diminati atau dibutuhkan oleh masyarakat, karena dengan pendidikan formal di sekolah dirasa kurang membantu peserta didik memahami materi yang telah disampaikan oleh pengajar di sekolah. Menurut Wulandari, M. (2017). Lembaga Bimbingan Belajar (LBB) merupakan salah satu lembaga pendidikan non formal yang memberikan bimbingan di bidang akademis dengan menyesuaikan kebutuhan peserta didik. Tujuannya yaitu untuk meningkatkan kualitas akademik atau kompetensi dari peserta didiknya. Pembelajaran di sekolah yang kurang mampu diserap secara maximal dapat disempurnakan lagi melalui Lembaga Bimbingan Belajar. Banyak sekali Lembaga Bimbingan Belajar yang berdiri di Indonesia baik secara online maupun offline.

Akan tetapi pada kondisi sekarang ini mendorong para orangtua untuk lebih memilih Lembaga Bimbingan Belajar (LBB) dengan pembelajaran daring, karena mereka khawatir akan penyebaran covid-19. Selain itu, pembelajaran secara langsung atau tatap muka dirasa lebih menyenangkan dibandingkan dengan online karena cara pembelajaran lebih mudah dipahami dan penjelasan materi lebih rinci. Anak juga telah terbiasa akan pembelajaran tatap muka dari dulu, maka adanya penyebaran covid-19 yang berdampak pada semua aspek kehidupan utama Pendidikan yang saat ini diberlakukan pembelajaran online membuat anak belum terbiasa dengan strategi pembelajaran yang diberikan. Maka dengan hal ini, banyak orangtua yang mendukung serta mendaftarkan anaknya di Lembaga bimbingan Belajar (LBB) untuk menunjang tingkat pemahaman materi yang diberikan di sekolah lebih terperinci lagi. 
Akan tetapi disisi lain terdapat orangtua yang kurang setuju jika anaknya diikutkan Lembaga Bimbingan Belajar (LBB) baik online maupun offline dikarenakan sama saja dan tidak ada bedanya dengan sekolah online. Mereka beranggapan bahwa pembelajaran secara online tidak efektif. Peserta didik kurang mampu memahami materi yang diberikan oleh pengajar yang dikarenakan pada pembelajaran daring ini melalui media - media teknologi seperti laptop, hp dll yang mana banyak ditemukan suatu hambatan di dalamnya seperti pada gangguan signal, keterbatasan fasilitas yang dimiliki peserta didik maupun pengajar, tidak bertemu dengan teman sebaya secara langsung. Sehingga hambatan-hambatan tersebut yang menjadikan proses pembelajaran daring tidak berjalan dengan tepat, memicu berbagai anggapan dari orangtua. Bahwa Lembaga Bimbingan Belajar yang dilakukan secara online dianggap tidak efektif, karena strategi pembelajarannya sama seperti yang ada di sekolah online.

Maka dari berbagai permasalahan yang ada membuat penulis tertarik untuk mengkaji tentang dampak adanya pandemi bagi Lembaga Bimbingan Belajar (LBB) karena banyak sekali dampak dari penyebaran covid-19 tersebut, seperti pada yang dirasakan pihak Lembaga Bimbingan Belajar (LBB) yang mana banyak LBB terpaksa harus gulung tikar, karena tidak ada siswa pendaftar, dan banyaknya siswa yang memutuskan untuk keluar. Yang disamping itu, pihak LBB harus tetap membayar pajak tempat tersebut kemudian tetap harus membayar pengajar dalam LBB tersebut. Dampak ini juga dirasakan pihak orang tua dan pelajar itu sendiri dalam kebijakan yang telah dibuat oleh pemerintah akan pembelajaran daring saat ini.

\section{Metode}

Dalam penelitian ini penulis menggunakan pendekatan kualitatif. Berdasarkan pendapat dari Anderson \& Arsenault (2005), penelitian kualitatif merupakan bentuk pendekatan yang mengeksplorasi fenomena dalam pengaturan alami dan menggunakan multi-metode untuk menafsirkan, memahami, menjelaskan dan membawa makna kepada fenomena tersebut. Dari pemaparan diatas, peneliti memilih metode penelitian kualitatif dengan jenis pendekatan deskriptif. Pendekatan ini diharap mampu untuk menemukan dan memecahkan suatu persoalan mengenai dampak kebijakan pembelajaran daring bagi LBB. Dalam penelitian ini penulis melakukan pencarian data dari lokasi di beberapa daerah di Jawa Timur, yakni Kota Blitar, Kota Tulungagung, dan Kabupaten Ponorogo. Subjek yang dipilih adalah Lembaga Bimbingan Belajar (LBB) sebagai pendidikan non formal, yang mana terdapat tiga bimbingan belajar yang menjadi subjek penulis.

Teknik pengumpulan informan yang dilakukan dengan menggunakan teknik purposive sampling. Sugiyono (2010) menjelaskan purposive sampling merupakan teknik yang dilakukan guna menentukan sampel penelitian dengan berbagai pertimbangan tertentu untuk. Penentuan informan kunci didasarkan pada seseorang yang mempunyai kemampuan menjawab permasalahan yang diberikan oleh peneliti. Informan dalam penelitian ini adalah pemilik Lembaga Bimbingan Belajar dan pengajar di Lembaga Bimbingan Belajar yang ada di Kota Blitar, Kota Tulungagung, dan Kabupaten Ponorogo, Jawa Timur.

Metode pengumpulan data merupakan langkah penting dalam melakukan penelitian, karena data yang dikumpulkan akan dijadikan bahan analisis dalam penelitian. Metode pengumpulan data yang digunakan dalam penelitian yaitu: 


\subsection{Wawancara}

Menurut Irawati (dalam Singarimbun, dkk. 1989) menyatakan bahwa dengan wawancara peneliti akan mendapatkan berbagai informasi dengan cara bertanya langsung kepada responden. Pembicaraan antara peneliti dan responden hanya sebatas pada daftar pertanyaan yang sudah disusun. Wawancara adalah salah satu bagian yang penting dalam suatu penelitian. Pewawancara, responden, daftar pertanyaan, dan situasi wawancara merupakan faktor yang akan mempengaruhi arus informasi.

Bentuk wawancara yang dilakukan yaitu baku terbuka. Jenis wawancara ini menggunakan seperangkat pertanyaan baku. Urutan pertanyaan, kata-kata, dan cara penyajiannya sama untuk setiap responden. Pertanyaan mendalam cukup terbatas, sesuai dengan situasi wawancara dan kecakapan pewawancara (Moleong, 2005). Alasan peneliti memilih bentuk wawancara baku terbuka yaitu agar variasi hasil wawancara dapat dikurangi. Peneliti menyediakan 10 pertanyaan yang akan dijawab oleh responden. Pertanyaan memuat urgensi dari pembahasan topik agar peneliti dapat memperoleh data yang sesuai dengan pembahasan. Pertanyaan yang diberikan menggunakan Bahasa yang sederhana dan jelas guna mempermudah responden untuk memahami pertanyaan yang disediakan.

\subsection{Observasi}

Metode ini merupakan sebuah teknik pengumpulan data yang mengharuskan peneliti untuk turun lapangan dan mengamati beberapa hal yang berkaitan dengan data yang dipelukan (Patilima, 2007). Observasi adalah kegiatan penelitian sistematis dan sengaja dilakukan untuk melihat kondisi atau peristiwa pada setting penelitian. Penelitian ini dilakukan untuk mendapatkan data mengenai dampak kebijakan pembelajaran daring bagi LBB yang ada pada tiga wilayah di Jawa Timur. Pengamatan yang dilakukan dapat terkait dengan tempat, kegiatan pelaku dalam proses pembelajaran, maupun peristiwa yang terjadi selama pengamatan berlangsung.

\subsection{Studi Literatur}

Nazir (1988) menjelaskan bahwa studi literatur adalah alat untuk mengumpulkan data guna mengungkap berbagai teori yang relevan mengenai topik yang diteliti. Data yang diambil bersumber dari berita atau referensi dari internet yang dianggap relevan dengan isi penelitian. Studi literatur dilakukan dengan menelaah berita terkait dampak kebijakan pembelajaran daring di masa pandemi terhadap pembelajaran di LBB. Berbagai telaah literatur akan digunakan untuk pedoman dalam merumuskan topik dan tujuan penelitian.

Dalam melakukan analisis data menurut Bog dan Biklen (dalam Moleong, 2005) analisis data kualitatif berupaya bekerja dengan data, mengorganisasikan data, memilah-milah data menjadi satuan yang dapat dikelola, mensintesiskannya, mencari dan menemukan apa yang penting dan dipelajari serta memutuskan apa yang dapat diceritakan pada orang lain. Dengan analisis ini peneliti menyusun kata-kata dari hasil wawancara maupun pengamatan terkait data yang dibutuhkan kemudian dideskripsikan dan diringkas (Patilima, 2007). Penelitian akan menggunakan tiga alur kegiatan analisis seperti yang dikemukakan oleh Matthew dan Michael dalam Patilima(2007) sebagai berikut: (1) Reduksi data merupakan proses memilih, menyederhanakan, pengabstrakan, dan transformasi data yang ada dari catatan di lapangan. Data yang didapatkan kemudian digolongkan, diambil yang diperlukan, dan diorganisasikan 
sedemikian rupa sehingga dapat menghasilkan suatu kesimpulan dan kemudian diverifikasi. (2) Penyajian data yang sering digunakan dalam kualitatif yaitu teks naratif. Peneliti cenderung menyederhanakan informasi kompleks kedalam suatu bentuk yang disederhanakan, sehingga akan mudah dipahami. Berbagai data mengenai dampak pandem bagi Lembaga Bimbingan Belajar akan diolah dan disederhanakan lagi. (3) Penarikan kesimpulan hal ini merupakan proses akhir dari teknik analisis. Kesimpulan akhir tergantung pada besarnya sekumpulan catatan lapangan, pengkodean, penyimpanan, dan metode pencarian ulang yang digunakan, kecakapan peneliti, dan tuntutan sponsor. Tentunya akan ditemukan kesimpulan dari adanya dampak pandemi bagi Lembaga Bimbingan Belajar.

\section{Hasil dan Pembahasan}

\subsection{Pendidikan Non Formal}

Pendidikan nonformal merupakan salah satu sarana pembelajaran kepada masyarakat guna mendukung realisasi dan pengelolaan program yang dijadikan sebagai pengembangan program di masa depan (Miradj, S., \& Sumarno, S., 2014). Pendidikan ini kebanyakan mengarah pada kebutuhan pelajaran yang memberikan keuntungan pada peserta didik yang umumnya tidak disajikan pada pendidikan formal. Pendidikan non formal merupakan lembaga yang memberikan fasilitas pendidikan kepada masyarakat selain pendidikan formal maupun informal, juga menyediakan bagi masyarakat yang belum bisa mengikuti dan menyelesaikan pendidikan pada jenjang pendidikan formal. Pendidikan non formal sebagai penambah pendidikan formal, apalagi di era modern ini banyak sekali pendidikan non formal ditemukan ditengah-tengah masyarakat.

Banyak sekali contoh pendidikan non formal di Indonesia seperti TPA (Taman Pendidikan Alquran), kursus memasak, kursus menjahit, homeschooling, pramuka, les bahasa Inggris dan masih banyak sekali. Akan tetapi disini penulis hanya membahas pendidikan non formal yakni Lembaga Bimbingan Belajar, dimana LBB sebagai penunjang pembelajaran di sekolah formal yang saat ini terdampak pandemi covid-19 sehingga mengharuskan belajar dirumah saja melalui jaringan atau daring. Visi lembaga bimbingan belajar secara umum adalah untuk meningkatkan kualitas akademik peserta didik (Wulandari, M., 2017). Kebanyakan lembaga bimbingan belajar menerapkan metode belajar yang klasikal dengan jumlah anak yang terbatas dan materi pelajaran telah disiapkan oleh lembaga bimbingan belajar.

\subsection{Dampak Kebijakan Pemerintah terkait pembelajaran daring pada LBB}

Suwitri (2008) menjelaskan bahwa kebijakan publik merupakan segala aktivitas guna memenuhi kebutuhan masyarakat yang umumnya ditetapkan oleh pihak pemerintah. Suatu kebijakan yang dibuat tentunya untuk mencapai tujuan tertentu. Pada tanggal 15 Maret 2020, Presiden Republik Indonesia menetapkan kebijakan bekerja, belajar, dan beribadah dari rumah. Kebijakan tersebut dinamakan Work From Home. Semua kegiatan orientasinya tidak boleh melalui tatap muka secara langsung, termasuk kegiatan belajar-mengajar di berbagai jenjang pendidikan baik formal maupun informal.

Dengan adanya kebijakan tersebut tentunya berdampak pada lembaga pendidikan di Indonesia khususnya lembaga bimbingan belajar (LBB). Penyelenggaraan pembelajaran di LBB yang awalnya dilakukan secara tatap muka (bertemu langsung) diharuskan beralih ke 
pembelajaran dalam jaringan (daring). Akibatnya, sementara waktu peserta didik memilih untuk tidak melanjutkan pembelajaran di LBB. Hal tersebut juga berdampak kepada para pengajar di LBB, imbasnya pendapatan yang diterima menjadi berkurang.

Penurunan pendapatan bimbingan belajar ini terjadi karena mereka kalah saing dengan sekolah formal, yang mana sekolah formal telah memberikan metode pembelajaran daring dan pemberian tugas. Oleh karenanya, fungsi bimbingan belajar sebagai pendukung pembelajaran sekolah formal menjadi berkurang. Pada akhirnya para tenaga pendidik di lembaga bimbingan belajar mendapat penurunan gaji yang sangat drastis. Bahkan beberapa pengajar ada yang menerima gaji tidak sampai setengahnya.

Berdasarkan data yang didapatkan dari Lembaga Bimbingan Belajar Progress sebagian orang tua menganggap bahwa pembelajaran daring kurang efektif sehingga mereka lebih memilih mengalihkan pengeluaran untuk hal lain yang mendesak. Bahkan ada pula pemilik lembaga bimbingan belajar lain yang terpaksa menutup sementara salah satu cabang untuk memangkas beberapa biaya sewa. Hal tersebut dialami oleh Lembaga Bimbingan Belajar Empowerment.

Perlu dipahami bersama bahwa kebijakan yang dibuat tentu sudah didasarkan pada pertimbangan tertentu. Selalu ada dampak positif dan dampak negatif mengenai kebijakan yang telah ditetapkan oleh pemerintah. Maka, diharapkan berbagai komponen masyarakat dapat memakluminya secara bijak. Adapun solusi lain yang sebaiknya diterapkan yakni pemberian kesempatan bagi para lembaga bimbingan belajar untuk melakukan pembelajaran daring dengan menetapkan protokol kesehatan di setiap pertemuannya.

Lembaga bimbingan belajar yang diperbolehkan mengajar dengan bertatap muka secara langsung juga perlu mengurangi jam pertemuan dan membatasi jumlah siswa di setiap kelompoknya. Pemberian kebijakan tersebut ditetapkan pada wilayah yang zona hijau atau memiliki penyebaran covid-19 yang rendah. Hal itu juga akan membangkitkan kepercayaan masyarakat terhadap pelayanan dan keamanan di lembaga bimbingan belajar. Mengingat bahwa lembaga bimbingan belajar cukup efektif untuk mendampingi para siswa yang kemungkinan besar belum dapat memahami materi yang diajarkan di sekolah. Sehingga adanya lembaga bimbingan belajar efektif untuk dapat membantu peserta didik yang belum sepenuhnya menguasai materi di pendidikan formal.

Jika memang daerah tersebut termasuk zona darurat atau zona merah, maka LBB dapat beralih dalam proses pembelajarannya melalui daring atau online. Pelaksanaan kebijakan ini perlu dipertimbangkan kembali karena karena beberapa masyarakat masih khawatir akan protokol kesehatan yang diterapkan di lembaga bimbingan belajar. Berdasarkan data yang didapatkan kebijakan daring juga kurang memihak pengajar terlebih mengenai kesejahteraan pengajar maupun staf lembaga bimbingan belajar di tengah pandemi. Misalnya saja terkait dengan bantuan paket data yang saat ini dirasakan oleh peserta didik saja, padahal bantuan paket data juga sebenarnya dibutuhkan oleh pengajar bimbingan belajar mengingat mereka juga tidak semuanya memiliki ekonomi yang sudah mumpuni.

\subsection{Teori Belajar Kognitif Sebagai Resolusi Permasalahan Bagi LBB}

Teori belajar kognitif menekankan pada belajar merupakan suatu proses yang terjadi dalam akal pikiran manusia. Karenanya belajar adalah hal yang dilakukan dalam diri manusia 
dengan usaha yang mana dari hal tersebut membawa suatu perubahan diri manusia dalam bentuk suatu pengetahuan, pemahaman, tingkah laku, keterampilan, serta sikap yang bersifat relatif dan berbekas (Given, 2014). Maka hal ini belajar menurut teori kognitif tidak melihat dari hasil belajar di masing masing peserta didik namun pada hal ini lebih terfokus pada proses pembelajaran setiap anak tersebut. Dalam suatu proses pembelajaran tersebut perlu ada aspek pendorong seperti aspek internal (keluarga) dan aspek eksternal (lingkungan).

Aspek keluarga merupakan aspek utama dalam proses perkembangan anak berupa meniru hal-hal yang baru dari tingkah keluarganya. Maka, keluarga yang harmonis dapat menjadikan anak berkembang dengan baik. Kemudian faktor lingkungan terlihat pada interaksi dengan anggota individu lainnya, yang mana anak dapat berperilaku tepat pada nilai dan peraturan lingkungan yang telah berlaku. Anak akan belajar dan meniru apa yang menjadi kebiasaan dari lingkungannya, sehingga lingkungan yang baik akan menjadikan proses perkembangan anak menjadi baik. Namun jika lingkungan anak tersebut buruk, proses perkembangannya anak juga akan buruk.

Pada bagian ini penulis akan menjelaskan tentang teori kognitif yang dapat digunakan sebagai resolusi permasalahan pembelajaran daring bagi lembaga bimbingan belajar(LBB). Pola pembelajaran daring yang belum sesuai dengan keadaan saat ini yang mana berakibat adanya peran ganda pada orangtua dalam mendampingi peserta didik serta tidak sesuai dalam teori kognitif tersebut. Peran yang dimiliki orangtua dalam keadaan saat ini berakibat pencapaian suatu penerimaan pengetahuan anak menjadi menurun, maka hal ini sangat berbeda pada strategi pembelajaran sebelum terjadi pandemi Covid-19. Teori kognitif ini terfokus pada proses belajar yang bukan saja melibatkan hubungan antara stimulus dan respon, tetapi ditentukan berdasarkan persepsi serta pemahaman yang diterima seseorang dalam situasi yang kaitannya pada tujuan belajarnya

Dalam aktivitas pembelajaran siswa, pendidik diharapkan memberikan umpan balik terhadap siswa. Sehingga dalam hal tersebut pendidik diwajibkan untuk tetap berinteraksi dan berkomunikasi terhadap berjalannya pembelajaran yang mana dapat mendorong siswa dalam dalam mengerjakan tugas. Namun, pengalaman penulis serta fakta yang ada disekitar saat ini yang mendapatkan peran tersebut justru orang tua dimana para orang tua dituntut untuk mendidik serta mendorong dalam berjalannya pembelajaran anak dirumah

Kondisi lapangan menunjukkan permasalahan cukup besar muncul saat wabah Covid-19 merajalela seperti status sosial orang tua yang berubah, beragam kebiasaan pemakaian gawai oleh peserta didik, maupun penurunan daya guna saat transfer pengetahuan dari pendidik kepada peserta didik terjadi. Penulis berpendapat bahwa proses tersebut tidak hanya meliputi penyampaian materi belajar, melainkan harus selaras dengan prinsip kognitif yang memicu respon peserta didik. Hal itu dapat terwujud pada perspektif mereka ketika menanggapi suatu persoalan. Pendidik sepatutnya memberikan bimbingan dan contoh agar pembelajaran berjalan sesuai harapan. Maksud tersebut tidak didapati pada model belajar online sebab fakta memperlihatkan tugas yang diberikan pengajar justru dituntaskan oleh orang tua murid tanpa pendampingan penuh dari guru.

Pola pembelajaran harus tersusun secara menyeluruh dengan pengukuran yang tepat terhadap tujuan pembelajaran untuk meningkatkan kapasitas diri. Sudah seharusnya pendidik mengaplikasikan peran mereka pada pembelajaran online dengan tidak semata-mata memasrahkan setumpuk tugas pada wali murid dan peserta didik itu sendiri tanpa didampingi 
dan diselingi pengantar yang disesuaikan dengan daya serap siswa. Akan tetapi pada kurikulum darurat di era pandemi ini pendidik kesulitan untuk melihat perkembangan yang dialami oleh peserta didik karena tidak dapat mengetahui langsung bagaimana proses pembelajaran yang telah dialami peserta didik.

Hal tersebut juga akan berdampak pada pendidikan non formal seperti Lembaga Bimbingan Belajar (LBB), yang mana semakin sedikit peserta didik yang mendaftarkan diri di LBB. Hal itu dikarenakan kondisi ekonomi orang tua yang menurun di masa pandemi, serta anggapan orang tua bahwa tidak perlu mendaftarkan anaknya pada LBB karena di sekolah formal saja sudah mendapatkan pembelajaran daring sehingga mereka memilih untuk menghemat pengeluaran dan mengalihkannya pada kebutuhan lainnya. Penulis berpendapat bahwa alangkah baiknya jika LBB tetap dibuka dengan mengindahkan aturan kesehatan covid-19 secara umum dan membagi peserta didik dalam beberapa kelompok serta mempertimbangkan kemudahan pengaksesan belajar tatap muka. Pengutamaan pembelajaran tatap muka tersebut diarahkan pada siswa jenjang sekolah menengah pertama, sekolah dasar, dan TK.

Melalui pembelajaran tersebut dapat memungkinkan adanya interaksi yang jelas untuk dapat membandingkan operasi belajar pada peserta didik secara kognitif. Pembelajaran tatap muka tersebut juga tetap berguna terhadap pola atau logika berpikir peserta didik dan dapat berkembang secara kompleks. Ambisi diselipkan bahwa orang tua tidak akan khawatir terhadap perkembangan anak dan pihak LBB pun tetap berkesempatan memberikan pengajaran bagi peserta didik. Mengingat pula bahwa sejauh ini keberadaan LBB telah memberikan pengaruh positif dan sangat bermanfaat bagi peserta didik maupun masyarakat luas.Oleh karena itu, pemerintah perlu memaksimalkan penerapan teori kognitif dalam pelaksanaan pendidikan di Indonesia agar pembelajaran yang diberikan lebih bermakna melalui proses interaksi dengan lingkungan.

\section{Simpulan}

Pendidikan non formal merupakan lembaga yang memberikan fasilitas pendidikan kepada masyarakat selain pendidikan formal maupun informal, juga menyediakan bagi masyarakat yang belum bisa mengikuti dan menyelesaikan pendidikan pada jenjang pendidikan formal. Seperti contoh nya lembaga bimbingan belajar (LBB) yang mana saat ini diera pandemi tersebut LBB mengalami penurunan akan pendaftaran siswa, karena yang mana adanya kebijakan pemerintah mempengaruhi segala pembelajaran yang harusnya bertatap muka langsung menjadi berbasis online atau pembelajaran secara daring dirumah. Hal tersebut yang menjadikan para peserta didik harus menempuh pendidikan dirumah, hal ini peran menjadikan peran orang tua lebih utama dalam pengawasan serta membimbing anak belajar dirumah, dibandingkan sebelumnya yang mana guru menjadi peran utama dalam mendidik anak dalam hal akademis. Ada sebagian orangtua yang memilih LBB menjadi solusi untuk membantu anak dalam belajar, tetapi sebagian orang tua juga yang tetap membimbing anak dirumah diketahui juga pada masa pandemi ini perekonomi turun drastis. Hal inilah yang menjadikan sebagian LBB memilih untuk tutup karenanya tidak ada siswa yang mendaftar, pemerintah telah membuat kebijakan akan hal tersebut seperti belajar online seperti hal yang dilakukan sekolah formal, atau bahkan memberikan bantuan untuk menunjang prokol kesehatan bagi LBB yang telah izinkan untuk tatap muka. Oleh karena itu, pemerintah perlu memaksimalkan penerapan teori kognitif dalam pelaksanaan pendidikan di Indonesia agar pembelajaran yang diberikan lebih bermakna melalui proses interaksi dengan lingkungan dan 
bisa membuat Lembaga Bimbingan Belajar agar tetap bisa buka pada saat pandemik seperti ini.

\section{Daftar Rujukan}

Abdi, A. P. (2020). (https://tirto.id/guru-bimbel-terjepit-saat-corona-bersaing-pula-dengan-sekolah-fG18), diakses pada 23 November 2020.

Anderson, G., Anderson, G. J., \& Arsenault, N. (1998). Fundamentals of educational research. Psychology press.

Firman, F., \& Rahayu, S. (2020). Pembelajaran Online di Tengah Pandemi Covid-19. Indonesian Journal of Educational Science (IJES), 2(2), 81-89.

Given, K. B. (2014). Brain-Based Teaching: Merancang kegiatan belajar mengajar yang melibatkan Otak, Emosional, Sosial, Kognitif, Kinestetik, dan Reflektif. Bandung: Kaifa.

Humas Kemendikbud. (2020). (Online). (https://setkab.go.id/mendikbud-dan-mendagri-pastikan-kebijakanpembelajaran-saat-pandemi-dilaksanakan-kepala-daerah/), diakses pada 30 November 2020.

Humas Kemendikbud. 2020. (Online). (https://setkab.go.id/minta-masyarakat-tenang-presiden-saatnyabekerja-belajar-danberibadah-dari-rumah/), diakses pada 30 November 2020.

Miradj, S., \& Sumarno, S. (2014). Pemberdayaan masyarakat miskin, melalui proses pendidikan nonformal, upaya meningkatkan kesejahteraan sosial di Kabupaten Halmahera Barat. JPPM Uurnal Pendidikan dan Pemberdayaan Masyarakat), 1(1), 101-112.

Moleong, L. J. (2005). Metodologi Penelitian KualitatiF, Edisi Revisi. Bandung: PT. Remaja Rosdakarya.

Mona, N. (2020). Konsep isolasi dalam jaringan sosial untuk meminimalisasi efek contagious (kasus penyebaran virus corona di Indonesia). Jurnal Sosial Humaniora Terapan, 2(2).

Nazir, M. (1988). Metode Penelitian. Jakarta: Ghalia Indonesia.

Patilima, H. (2007). Metode Penelitian Kualitatif, Edisi Kedua. Bandung: Alfabeta.

Singarimbun, S., Masri, M., \& Effendi, S. (1989). Metode Penelitian Survei. Jakarta: LP3ES.

Sugiyono, S. (2010). Metode Penelitian Pendidikan. Bandung: Alfabeta.

Suwitri, S. (2008). Konsep dasar kebijakan publik. Semarang: Badan Penerbit Universitas Diponegoro.

Wulandari, M. (2017). Manajemen pembelajaran pada lembaga bimbingan belajar dalam meningkatkan kompetensi peserta didik (studi pada Lbb Klinik Belajar Edu Privat di Kota Baru Driyorejo Gresik). J+ PLUS UNESA, 6(1). 